\title{
EFFECT OF MORA (MORUS ALBA) L. ON ALLOXAN DIABETIC RATS ${ }^{1}$
}

\section{CONRADO F. ASENJO AND DELIA FERNÁNDEZ²}

The leaf of Morus alba L., commonly known as white mulberry, is widely used in Puerto Rico in the folk treatment of diabetes mellitus. The drug is administered orally in the form of an aqueous infusion several times per day.

A perusal of the literature on mulberry reveals that another species of this genus, Morus nigra L., is used in the Balkan countries as a folk remedy for diabetes, in the same manner that $M$. alba is used in Puerto Rico (1).

Bart (2) studied the hypoglycemic effect of aqueous infusions of $M$. nigra leaves on the blood of normal human subjects and found that maximum hypoglycemic action occurred 2 hours after the oral administration of the infusion.

No reference has been found in the literature regarding the use of $M$. alba in the treatment of diabetes mellitus, except the recent clinical investigation by Paniagua and Hernández (3) from our School, to which we shall refer later.

It is the purpose of the present communication to describe experiments done to determine if an aqueous infusion of $M$. alba leaves, prepared as it is commonly used in the folk medicine of Puerto Rico, has hypoglycemic activity when administered, per os, to alloxan diabetic rats.

Induction of diabetes in rats by the intravenous injection of alloxan. Young albino rats from our colony (Wistar strain) were used. They were maintained on our stock colony ration before and after injections. ${ }^{3}$ These animals ranged between $40-80$ grams in weight at the time of injection. A 3 per cent solution of alloxan monohydrate was prepared in sterile distilled water immediately before injection.

In general the technic of Mann and Stare was used (4). The animal was placed in a mailing carton with the tail protruding through a hole in the center of a cork stopper used to close the carton. After cleaning the tail and giving a brisk rub with a dry cloth, or with a small amount of xylol when the veins were difficult to see, the needle was introduced level up, directly over the vein and on the distal one third of the tail. When blood appeared at the syringe nipple, the calculated volume of alloxan solution

${ }^{1}$ Cooperative project between the Agricultural Experiment Station of the University of Puerto Rico and the School of Tropical Medicine.

${ }^{2}$ From the Department of Chemistry and Nutrition, School of Tropical Medicine of the University of Puerto Rico, San Juan, P. R.

${ }^{3}$ Rockland rat diet. 
was injected. The dose of alloxan used was $60 \mathrm{mg}$. per kilo of body weight. This dose was recommended by Mann and Stare (4) as the most practical one to use, as it gives diabetic response in about $90 \%$ of the injected animals without causing injury to other organs than the pancreas.

In a period of 2 to 3 days the responding animals developed characteristic diabetic signs, such as hyperglycemia, glycosuria and polyuria.

Preparation of the infusion. Fresh leaves of Morus alba L. were obtained from a tree at the Agricultural Experiment Station at Río Piedras, P. R. The infusion was prepared by boiling approximately 100 grams of fresh leaves in $1500 \mathrm{ml}$. of distilled water for a period of about half hour. This infusion contained 0.5 grams of solids per $100 \mathrm{ml}$. and no detectable amount of reducing sugars.

Assay of the mora infusion. The mora infusion was administered in place of water for a period of 6 consecutive days. On the 5 th day the food was removed and the animals fasted for a period of 24 hours. At the end of this

TABLE 1

Blood sugar of alloxan diabetic rats under different treatments

\begin{tabular}{|c|c|c|c|c|}
\hline & $\begin{array}{c}\text { Stock colony } \\
\text { ration }\end{array}$ & $\begin{array}{c}\text { After 24 hrs. } \\
\text { fast receiving } \\
\quad \mathrm{H}_{2} \mathrm{O}\end{array}$ & $\begin{array}{c}\text { After } 24 \mathrm{hrs} \\
\text { fast receiving } \\
\text { mora infusion }\end{array}$ & $\begin{array}{l}\text { After } 24 \mathrm{hrs} \text {. } \\
\text { fast and } 2 \\
\text { units of insu- } \\
\text { lin on the } \\
\text { 22nd hour }\end{array}$ \\
\hline Number of observati & 18 & 10 & 11 & 8 \\
\hline Blood sugar mg. per $\mathrm{mm}^{3}$. & 394.5 & 132.4 & 122.5 & 73.2 \\
\hline Standard deviation ......... & \pm 50.5 & \pm 27.7 & \pm 28.7 & \pm 23.6 \\
\hline
\end{tabular}

asting period, a blood sample was taken from the tail and glucose was determined using the micro method of Folin and Malmros (table 1). During the last four days of the trial, records were kept of the daily fluid consumption as well as of the total excretion of urinary glucose (table 3).

Hypoglycemic action of insulin. After finishing the trials, 2 units of insulin $^{4}$ per kilogram of body weight were injected intraperitoneally, as a check, to eight of the diabetic rats. The rats thus injected had previously fasted for a period of 22 hours. Two hours later blood for glucose determination was taken from the tail of the animals.

\section{RESULTS}

Although the 24 hours fasting blood sugar of the mora treated rats was lower than that of the untreated ones, 122.5 and $132.4 \mathrm{mg}$. per cent, respectively (table 1), the difference between these two values was not statistically significant (table 2).

On the other hand, the injection of 2 units of insulin to the diabetic

${ }^{4}$ Insulin Mulford. 
animals previously fasted for a period of 22 hours, induced a significant decrease in the blood sugar 2 hours later; this value was $73.2 \mathrm{mg}$. per cent.

\section{TABLE 2}

Significance of differences observed between the blood sugars of the rats in table 1 that received different treatments

\begin{tabular}{|c|c|c|c|c|c|}
\hline & $\begin{array}{c}\text { Differ- } \\
\text { ence }\end{array}$ & $\sigma_{\text {diff. }}$ & $\left|\begin{array}{c}\text { Degrees } \\
\text { of } \\
\text { freedom }\end{array}\right|$ & $t^{\dagger}$ & Remarks \\
\hline $\begin{array}{l}\text { Difference between fasted diabetics re- } \\
\text { ceiving } \mathrm{H}_{2} \mathrm{O} \text { and fasted diabetics re- } \\
\text { ceiving mora infusion. }\end{array}$ & 9.9 & 18.3 & 19 & 0.54 & $\begin{array}{l}\text { Difference not } \\
\text { significant }\end{array}$ \\
\hline $\begin{array}{l}\text { Difference between fasted diabetics re- } \\
\text { ceiving } \mathrm{H}_{2} \mathrm{O} \text { and fasted diabetics re- } \\
\text { ceiving } \mathrm{H}_{2} \mathrm{O} \text { and } 2 \text { units of insulin per } \\
\text { kilogram of body weight. }\end{array}$ & 59.2 & 18.3 & 16 & 3.24 & $\begin{array}{l}\text { Difference } \\
\text { highly sig } \\
\text { nificant }\end{array}$ \\
\hline $\begin{array}{l}\text { Difference between fasted diabetics re- } \\
\text { ceiving mora infusion and fasted dia- } \\
\text { betics receiving } \mathrm{H}_{2} \mathrm{O} \text { and } 2 \text { units of in- } \\
\text { sulin per kilogram of body weight. }\end{array}$ & 49.3 & 18.3 & 17 & 2.69 & $\begin{array}{l}\text { Difference sig } \\
\text { nificant }\end{array}$ \\
\hline
\end{tabular}

TABLE 3

Daily consumption of fluids and excretion of urinary glucose by alloxan diabetic rats

\begin{tabular}{|c|c|c|}
\hline & On $\mathrm{H}_{2} \mathrm{O}$ & On Mora Infusion \\
\hline (On the stock colony ration) & & \\
\hline Fluid intake $\mathrm{ml} . / 24 \mathrm{hrs} . \ldots \ldots \ldots$ & 36.7 & 36.7 \\
\hline $\begin{array}{l}\text { Urinary glucose gm. } / 24 \text { hrs... } \\
\text { (After } 24 \text { hrs. fast) }\end{array}$ & 0.77 & 0.88 \\
\hline Fluid intake $\mathrm{ml} . / 24 \mathrm{hrs} . \ldots \ldots$. & 5.9 & 8.9 \\
\hline Urinary glucose $\mathrm{gm} . / 24 \mathrm{hrs} \ldots$ & 0.12 & 0.12 \\
\hline
\end{tabular}

Another index that pointed to the ineffectiveness of the mora infusion was the 24 hour fasting urine glucose excretion. This remained the same in the treated as in the untreated animals: 0.12 grams per day (table 3).

\section{CONCLUSIONS}

These results indicate that, under the conditions of our experiment, an aqueous infusion of mora leaf, prepared as previously described, does not 
have hypoglycemic effect on alloxan diabetic rats nor does it reduce the excretion of glucose in the urine.

Our findings agree with those of Paniagua and Hernández (3). These investigators submitted to clinical test the same mora leaf infusion prepared by us as already described. Their test consisted of the oral administration of 1000-1500 ml. of the infusion each 24 hour period, for no less than 2 days, to diabetic patients standardized on diets supplying from 150-250 grams of carbohydrate per day. They did not observe improvement in a single one of the 5 patients thus treated. In all of them the blood sugar increased when mora infusion per os replaced regular insulin treatment.

\section{REFERENCES}

1. Leclerc, L. H. Action hypoglycemiante de la feuille du Murier noir. (Morus nigra L.). Press Méd. 42: 1522 (1934).

2. BART, C. Action hypoglycemiante des feuilles du murier. Compt. rend. soc. biol. 109: 897-899 (1932).

3. Paniagua, M. E. and F. Hernández-Morales. Use of Mulberry leaf in diabetes mellitus. Bol. Asoc. Med. P. R. 42: 79-84 (1950).

4. Mann, G. V. and F. J. Stare. Nutrition and Experimental diabetes. The diabetic response of wealing rats to intravenous doses of alloxan. J. Lab. Clin. Med. 33: $1161-1164$ (1948).

5. Hawk, P. B., B. L. Oser and W. H. Summerson. Practical Physiological Chemistry, 12th ed., pg. 256, The Blakiston Co., Phila. (1947). 